\title{
Madness of the East: Demystifying the Colonialist Perspective on Frank Swettenham and Hugh Clifford's Amok ${ }^{1}$
}

\author{
Foong Soon Seng \& Gheeta Chandran
}

\begin{abstract}
The colonialist's biased depictions of the East as backward, chaotic and barbaric place are debunked in Edward Said's Orientalism. The exercise of power over the Orient is relentlessly maintained through a set of dichotomies, namely, civilized/savage, reason/emotional and so on. Under the colonialist discourse, the natives are often being associated with negative connotations in both written and spoken colonialist discourses. Hence, the representations of the Orient as savages in the colonialist discourse are in support of the act of colonization in the East. Both Hugh Clifford and Frank Swettenham were British colonial officers based in Peninsula Malaya and they have recorded their experiences in a series of sketches based on the Malay characters they have encountered during their stay in Malaya. Therefore, the present study aims to re-examine the concept of amok and demystify the colonialists' facile generalization of the culture-bound syndrome in the written discourse through Clifford's In Court and Kampong and Swettenham's Malay Sketches. The amok syndrome is characterized by a sudden violent outburst from a person that is caused by an insult, a cultural phenomenon habitually found in the East. The homogenization of native Malays as prone to the culturebound syndrome, namely amok, is shown via Clifford's "The Amok of Dato Kaya BijiDerja" and Swettenham's "amok". Consequently, the association of the amok syndrome in the Malay culture creates a stigmatized and biased perception that Malay men are prone to this mental disorder due to the infrequent occurrences of the malady among the non-Malays in the colonialist discourse.
\end{abstract}

Keywords: Colonialist Discourse, Madness, Amok, Culture-Bound Syndrome, Malay Peninsula.

\subsection{Introduction}

Here is Mr. Birch in the bath-house, come, let us kill him," and followed by three or four others shouting, "Amok, amok," they leapt on to the floating timbers and thrust their spears through the open space in the front of the house. (Swettenham, 1895/2016, p. 166)

Stereotypical depictions of Malaya as an uncivilized, wild and primitive land

\footnotetext{
${ }^{1}$ Amok, or also commonly known as "amuck" is a cultural syndrom, typically afflicted to Malay man who is violently uncontrollable. This involves a sudden mass assault with the intent to murder everyone in sight.
} 
penetrate the colonialist discourse, written biased about the Eastern soil. Nevertheless, in Edward Said's Orientalism, the colonialist's biased depictions of the East as backward, chaotic and barbaric place are debunked. The negatively skewered representations of the Orient as savages in the colonialist discourse are in support of the act of colonization in the East. In order words, the natives are often being associated with negative connotations in both written and spoken colonialist discourses. For example, Frank Swettenham depicts Malaya as:

Malaya, land of pirates and the amok, your secrets have been well guarded, but the enemy has at last passes your gate, and the irresistible Juggernaut of Progress will have penetrated to your remotest fastness, slain your beasts, cut down your forest, 'civilised' your people, clothed them in strange garments, and stamped them with the seal of a higher morality. (Swettenham, 1895/2016, p.x)

Under the colonialist discourse, the portrayal of the natives as partial human beings is thus established in order to maintain the western superiority. The exercise of power over the Orient is relentlessly maintained through a set of dichotomies, namely civilized/savage, reason/emotional and so on. It was stated in the Malay Sketches that "indigenous native races whose numbers are few must disappear or conform to the views of a stronger will and a higher intelligence." (Swettenham, 1895/2016, p. x) In the similar vein, the rhetoric of mental illness and disability has supplementary intensified the colonialist discourse. The connection of Malay men to the discourse of madness posits important questions; for example, that of the possibility of homogenizing the native male Malays as susceptible to the cultural-bound syndrome. In "The Real Malay", Swettenham depicts the Malays to be:

Intolerant to insults or slight; it is something that to him should be wiped out in blood. He will brood over a real or fancied stain on his honour until he is possessed by the desire for revenge. If he cannot wreck it on the offender, he will strike out at the first human being that comes in his way, male or female, young or old. It is this state of blind fury, this vision of blood, that produces the amok. (Swettenham, 1900, p. 10-11)

The excerpt above further suggests the innate nature of the Malay natives to possess a savage mentality in Malaya Peninsula. Hence, it justifies the native Malays as uncivilised and barbaric; who are essentially solving problems with violence. It establishes a need for governance and opens up the door for the colonialist to colonize Malaya because the indigenous people failed to govern themselves. Eddie Tay (2011) further exclaims that "amok signifies the native's failure at what we may call the government of self." (p. 24)

Hence, the biased perception is intensified when Swettenham (1900) claims that "he [a Malay man] is courteous and expects courtesy in return, and he understands only one method of avenging personal insults" (p. 11) in "The Real Malay". According to Syed Muhd Khairudin Aljunied (2011), the amok phenomenon "becomes widespread upon the imposition of European rule in the Malay world.” (p. 18) Mohamad Yuss of (1983) asserts that:

Malays are a fighting race. That was how the British found them when they first came to Malaya. After the Rulers had agreed to accept British protection the Malays gave up fighting and became peaceful in their way of life. This does not mean that the spirit of fighting has died down. Normally a Malay is polite and tactful but one should not push him too far. The fighting spirit in him comes out again and he is likely to run amok... [amok] means that a Malay laboring under a grievance either real or imagined would go all out for revenge and in the process he puts very little value on 


\section{Madness of the East: Demystifying the Colonialist Perspective on Frank Swettenham and Hugh Clifford's Amok}

his life. (p. 325)

The word, amok, is derived from a Malay term meng-amok, which commonly means "irrational-acting individual who causes havoc." (Saint Martin, 1999, p. 66) Additionally, Saint Martin explains "the term also describes the homicidal and subsequent suicidal behavior of mentally unstable individuals that results in multiple fatalities and injuries to others." According to $\mathrm{Wu}$ (2018), amok is "a pattern of indiscriminate, homicidal behavior supposedly observed mainly amongst Malay-Muslim men." The definition of amok syndrome, a cultural phenomenon habitually found in the East, is characterized by a sudden violent outburst from a person that is caused by an insult. In The Real Malay, Swettenham makes reference to the Malay phenomenon and in particularly cites Mr. James Richardson Logan, a renowned writer and distinguished ethnologist who knows the Archipelago very well. He states:

These amoks result from idiosyncrasy or peculiar temperament which all who have much intercourse with them must have observed, although they cannot account for or thoroughly understand. It consists of proneness to chronic disease of feeling, resulting from a want of moral elasticity, which leaves the mind a prey to the pain of grief, until it is filled with a malignant gloom and despair, and the whole horizon of existence is overcast with blackness (...) the great majority of pengamoks ${ }^{2}$ are monomaniacs (...) it is clear that such a condition of mind is inconsistent with a regard for consequences. (Swettenham, 1900, pp. 245-246)

Hence, amok has become a psychological illness and Eddie Tay (2011) asserts that "since the arrival of the British, the number of incidences of Malays running amok has decreased." (p. 24) This is one of the opportunities opened for the British to justify their ruling in Malaya. In The Real Malay, Frank Swettenham further consolidates that fact that the British is more familiar with the signs of insanity and its method of treatments initiated by hospital or lunatic asylums. Swettenham further proclaims "amok is an ancient practice in Malaya and the Malays are of different temperament from the others" (p. 254) who have the tendency of being diagnosed with such mental sickness.

In addition, AsakoNakai(2000) indicates that "the use of the phonetic transcription of a Malay word 'amok' instead of a translation such as 'indiscriminate slaughter' reinforces the image that amok-running is a distinctly Malay phenomenon supposedly unknown to European society." (p. 62) Nakai creates a term, "frenzied Malay" to denote the initial meaning of the Malay word. The usage the Malay term in the colonialist discourse reinforces the logic underpinning the rational/emotional or sanity/insanity dualistic structures. It strengthens the colonizer's position to govern the natives as a superior race in Malaya. The association of the amok syndrome in the Malay culture by the British colonialist officers creates the biased perceptions that the Malays are prone to this mental disorder due to the infrequent occurrences of the malady among the non-Malays in the colonialist discourse. Eddie Tay (2011) resonates the concern of the "unhomely image of Malay subjects who run amok" (p. 15) and he further describes the cultural-bound syndrome:

Amok as a colonialist motif is a response to the condition of not being at home; it is a trope that seeks to create an environment hospitable to the colonial enterprise. However, as we shall see, this trope is often unstable in its range of signification, to the extent that it exceeds its colonialists framing of Malaya. (p. 16)

\footnotetext{
${ }^{2}$ Man who runs amok.
} 
Conversely, Tun Dr. Mathathir bin Mohamad (2008), the current Prime Minister of Malaysia once addresses the amok phenomenon in his book entitled The Malay Dilemma. He mentions:

Amok represents the external physical expression of the conflict within the Malay, which his perpetual observance of the rules and regulations of his life causes in him. It is a spilling over, an overflowing of his inner bitterness. It is the rupture of the bonds which binds him. It is the final and complete escape from reason and training. The strain and the restraint on him are lifted. Responsibility disappears. Nothing matters. $\mathrm{He}$ is free. The link to the past is severed, the future holds nothing more. (p. 151)

$\mathrm{Wu}$ exclaims that Tun Dr. Mahathir's claims echoes "the familiar colonial discourse that European intervention or 'civilisation' eradicated amok in Malaya." In the subsequent paragraph, Tun Dr. Mahathir argues that:

Today the amok is only a legend. Civilization has subdued the Malay. He still harbours his resentment, but he is better able to control it. He is better a better man for it. But it remains an essential part of his make-up, a basic part of his character. (p. 152)

In 1995, Adman Salleh, a filmmaker explores "the connection between hypermasculine violence" in his film entitled "Amok". (Khoo, 2006, p. 193) Khoo provides the rationale justification behind the cultural-bound syndrome that the amok phenomenon "represents the external physical expression of the conflict within the Malay which his perpetual observance of the rules and regulations of his life causes in him." (p. 193) Therefore, amok articulates the pengamok's "repressed masculinity".

As mentioned by Tun Dr. Mahathir, amok is just "another facet of the Malay character." (p. 151) As this homicidal mania is typically associated to Malay men, the present study aims to demystify the colonialists' facile generalization of the culture-bound syndrome in the written discourse. Consequently, the present study aims to re-examine the concept of amok through Hugh Clifford's In Court and Kampong and Sir Frank Athelstane Swettenham's Malay Sketches. Both Clifford and Swettenham were British colonial officers based in Peninsula Malaya and they have recorded their experiences in a series of sketches based on the Malay characters they have encountered during their stay in this Eastern soil. Their motives were apparent, that was to promote Imperial voyage in the East. In these series of sketches, the homogenization of native Malays as prone to the culture-bound syndrome, namely amok is shown via Clifford's "The Amok of Dato Kaya Biji Derja" and Swettenham's “Amok”.

\subsection{Hugh Clifford's In Court and Kampong and Swettenham's Malay Sketches:An analysis on "The Amok of Dato Kaya BijiDerja" and "Amok"}

The colonizers' limited understanding on the native Malays in Peninsula Malaya poses a discriminatory assumption that they are prone to mental illness. The examples of tales, and sketches taken from Hugh Clifford and Sir Frank Swettenham initiate the logical idea of governance that is not based on force. Thomas Williamson (2010) argues that "the circulation of their ideas [about the amok phenomenon], crucially but not solely in newsprint, curated amok into a prominent, durable colonial concept." (p. 39) It further necessitates amok as the homicidal tendencies among the Malay community in Peninsula Malaya. 
Hugh Clifford's "The Amok of Dato Kaya Biji Derja" in In Court and Kampong reflects the superficial descriptions of the Malays as a "figure of a wild-eyed, long-haired, blood-smeared, howling and naked savage." (Clifford, 1897/2016, p. 72) Despite indicating that "such acts [running amuck] are not peculiar to the Malays" (Clifford, 1897/2016, p. 73, the metaphor of a madman is represented through these vivid images that further distinguish between the colonizer from the colonized. Hence, the colonizer is considered as the savior who rescues these natives from backwardness. Clifford also attempts to describe the amok phenomenon that "All Malays have the greatest horror of suicide, and I know of no properly authenticated case in which a male Malay has committed such a act, but I have known several who ran amok when a white man, under similar circumstances, would not improbably have taken his own life." (p. 74) Clifford constantly makes an effort to differentiate the Malays from the white men. Thus, he defines amok as:

Often enough, something trivial begins the trouble, and, in the heat of the moment, a blow is struck by a man against one whom he holds dear, and the hatred of self which results, causes him to long for death, and to seek it in the only way which occurs to a Malay namely, by running amok. (Clifford, 1897/2016, p. 74)

The excerpt above paints a picture of a hot-blooded Malay man who cannot possibly control his emotions and hence, turns into a psychotic murderer. It matches the descriptions of the natives in the colonialist discourse, where they are often perceived as emotionally unstable and savagely violent. To quote from $\mathrm{Wu}$ (2018), she asserts that:

Colonial attempts to understand amok were founded upon an inherently occidental framework of analysis, which saw Malay violence not as culturally-sanctioned but as an affirmation of the primitive character of native men silently churning beneath their self-effacing and timid veneers." (p. 176)

On top of that, Clifford (1897/2016) further elaborates the characteristics of this Malay phenomenon:

A man who runs amok, too, almost always kills his wife. He is anxious to die himself, and he sees no reason why his wife should survive him, and, in a little space, become the property of some other man. He also frequently destroys his most valued possessions, as they have become useless to him, since he cannot take them with him to that bourne whence no traveller returns. (p. 74)

At the beginning of the short story, Clifford describes the origin of To' Kaya, whereby he was appointed by the Sultan to assist Jusup who is a commoner. Dato' Kaya Biji Derja describes him as someone with "no particular birth, possessed no book learning (...) and was not even skilled in the warrior's lore." (p. 75) To' Kaya prefers settling down "to live the orderly domestic life for which he was best fitted" (p. 75) and the entitlement of the high post given to him "had interrupted the even tenor of his ways." (p. 75) The background of To' Kaya is mentioned at the earlier part of the short story illustrates the nature of the Malay natives; who are commonly described as lazy, indolent, barbaric and treacherous under the colonialist discourse. The denigrating views of the Malays propose the idea of colonialist's intervention into the socio-political system in Malaya.

In Clifford's "The Amok of Dato Kaya BijiDerja", the incident is mainly occurs due 
to a minor misunderstanding; where "To' Kaya mistook stringy piece of egg, in his wife's sweetmeats, for a human hair (...) [Malays] believed that a hair in his food betokened that the dish was poisoned, and he refused to touch it, hinting that his wife desired his death." (p. 76) The petty argument apparently leads to a heated verbal abuse in the following day after To' Kaya returned home after tending his sick father. The wife accuses him for infidelity. "He [To'Kaya] cried to her to unbar the door, which, at length, she did, using many injurious words the while, and he, in his anger, replied that he would shortly have to stab her to teach her better manners." (p. 76) As discussed earlier, the cause of amok is mainly due to insults. Therefore, it shoves To' Kaya to his limit when his wife accuses him for infidelity and scolds him with detrimental words. Throughout the short story, the cause of To' Kaya's mental illness is not discussed. The issue of race is brought up when Clifford makes a comparison between the Malays as opposed to the white men.

However, Clifford makes a logical connection that amok is "caused by a condition of mind, which may result from either serious or comparatively trivial causes (...) makes a native weary of life." (p. 73) Clifford claims that "Malay amok results from a condition in mind which is described in a vernacular by the term sakithati, sickness of liver, that organ, and not the heart, being regarded as the centre of sensibility." (p. 73) To' Kaya unceasingly kills his relatives and friends and towards the end of the short story, Clifford explains that:

This [amok] is a sufficiently big butcher's bill for a single man, and he had done all this because he had had words with his wife, and, having gone further than he had intended in the beginning, felt that it would be unclean thing for him to continue to live upon the surface of a comparatively clean planet. A white man who improbably have committed suicide in his remorse, which would have been far more convenient for his neighbours, but that is one of the many respects in which a white man differs from a Malay. (Clifford, 1897/2016, p. 85)

Sir Frank Swettenham reports the "Amok" incident involving a Malay man, who carries a spear and a golok ${ }^{3}$, killing his family members and everyone he sees. The gruesome incident occurs at Pasir Garam near Perak River. Bearing the religious title of being an $\mathrm{Imam}^{4}$, Mamat serves the community by providing religious guidance. However, Swettenham depicts Mamat as an outraged and irrational person. He asserts that:

Mention has been made of the Malay amok, and, as what, with our happy faculty for mispronunciation and misspelling of the words of other languages, is called "running amuck," is with many English people their idea of the Malay, and that a very vague one, it may be of interest to briefly describe this form of homicidal mania. (Swetthenham, 1895/2016, p. 33)

Imam is a perfectly normal man with respectable status among the community. He is depicted as a man of forty years old, of good repute with his neighbours. Swettenham states that "I never heard of any cause suggested why this quiet, elderly man of devotional habits should suddenly, without apparent reason, develop the most inhuman instincts and brutally murder a number of men, women, and children, his nearest relatives and friends." (p. 36) "The Imam went up to his brother-in-law, took his hand and asked for his pardon. He then approached his own wife and similarly asked her pardon, immediately stabbing her fatally in the abdomen with the golok." (Swettenham, 1895/2016, p. 34) A commotion ensued between

${ }^{3}$ Golok is a sharp, pointed cutting knife.

${ }^{4}$ Imam is a title commonly refers to the priest in an Islamic mosque, often a respectable person in a kampong (a village/community). 


\section{Madness of the East: Demystifying the Colonialist Perspective on Frank Swettenham and Hugh Clifford's Amok}

Imam Mamat and his brother, who tried to protect his sister-in-law. Imam stabbed his brother in the heart, killing him instantly.

Meng-amok is to make a sudden, murderous attack, and though it is applied to the onslaught of a body of men in war time, or where plunder is the object and murder the means to arrive at it, the term is commonly used to describe the action of an individual who, suddenly and without apparent cause, seizes a weapon and strikes out blindly, killing and wounding all who come in a way, regardless of age or sex, whether they be friends, strangers, or his own nearest relatives. (Swettenham, $1895 / 2016$, p. 33)

The cause of Imam's sudden outbreaks of attacking his wife and friends is unknown. Imam is 'silenced' and behaves as if he was under trance throughout the entire story. As mentioned earlier, he asks pardon and greets others as usual, but his behaviours starts to change drastically and he goes amok with anyone he sees [or anyone who seems to block his way]. He addresses Uda Majid [Imam's friend] with "Yes, I know you, but my spear does not." (p. 34) He attacks and stabs his friend twice before he died. The mass murders continue with several others, killed six people and wounded four.

Imam's absurd behaviour of killing indiscriminately portrays his unstable emotions. In another incident, 'Lasam [Imam's friend] asked the Imam what he wanted, and he said he wished to be allowed to sleep in the house. He was told he could do so if he would throw away his arms, and to this the Imam replied by an attempt to spear Lasam through the window. Lasam fought with the Imam and successfully wounded him. Imam died from loss of blood after receiving his wound.

Towards the end of the short story, Swettenham provides a medical explanation to this uncanny Malay phenomenon. The post-mortem examination of the body of Imam Mohamed (Mamat) reveals that Mamat "died from haemorrhage from a wound on the outer side of his thigh; the internal organs were healthy except that the membranes of the right side of the brain were more adherent than usual." (Swettenham, 1895/2016, p. 36) Although scientific explanation was given, the representation of Mamat's manic behaviours further strengthen the Malay innateness towards such malady.

\subsection{Conclusion}

The colonialist discourse attacks the nativity of the Malays through their innate nature of being irrational and emotional. The amok phenomenon is enacted varyingly through different domains such as literature, journalism, medicine, and film. The white men's constant portrayal of Malay men as the peng-amok in their written discourse has adhesively associated them to this mental illness. Thus, the association of amok phenomenon to the Malays community continues to undermine their positions in the Malaya peninsula. It impedes the societal consciousness that Malays are essentially violent in nature. The amok phenomenon is embalmed as the cultural-bound syndrome among the Malay community has strengthened the white men's position in Malaya peninsula. The white men's overt emphasis on their civilizing mission provides consents to them to humanize the indigenous on the amok phenomenon. The colonial officers such as Hugh Clifford and Sir Frank Swettenham's narratives unveil the overt nature of the civilizing mission embarked by the Whites in Malaya. Assumptions on the indigenous natives are overgeneralized and these assumptions have strengthened their position in the East. The colonial officers' written tales and short story on the native Malays 
further ascertains the fact that they are uncivilized. Nevertheless, the insubstantial facts and flimsy discussions on the amok phenomenon in the selected tales negate some of the unexplained causes of this cultural-bound syndrome. Thus, metaphor of amok transpires as a form of control over the indigenous natives in the East.

\section{References}

Clifford, H. (2016). In court and kampong. Silverfish Books. (Original work published 1897).

Khoo, G. C (2006). Reclaiming adat: Contemporary Malaysian film and literature.

NUS Publishing.

Mahathir bin Mohamad. (2008). The Malay dilemma. Singapore: Marshall Cavendish.

Mohamad Yusoff (1983).Decades of change: Malaysia 1910-1970s. Kuala Lumpur: Pesaka.

Nakai, A. (2000). The English book and its marginalia: Colonial/postcolonial literatures after heart of darkness. Rodopi.

Saint-Martin, M. L. (1999). Running amok: A modern perspective on a culture-bound syndrome. The Primary Care Companion to The Journal of Clinical Psychiatry, 1(3), 66-70.

Swettenham, F. A. (2016). Malays sketches. Kuala Lumpur: Silverfish Books. (Original work published 1895).

Swettenham, F. A. (1900). The real Malay. J. Lane.

Syed Muhd Khairudin Aljunied (2011). A theory of colonialism in the Malay world. Postcolonial Studies, 14(1), 7-21.

Tay, E. (2011).Colony, nation, and globalisation: Not at home in Singaporean and Malaysian literature. Hong Kong University Press.

Williamson, T. (2010). Researching amok in Malaysia. In A. Digby, W. Ernst \& P. B. Mukharji (Eds.), Crossing colonial historiographies: Histories of colonial and indigenous medicines in transnational perspective (pp. 37-56). Cambridge Scholars Publishing.

Wu, J. C. (2018). Disciplining native masculinities: Colonial violence in Malaya, 'land of the pirate and the amok'. In P. Dwyer \& A.Nettelbeck (Eds.),Violence, colonialism and empire in the modern world (pp. 175-195). Palgrave Macmillan.

\section{$\underline{\text { Bio-note }}$}

Foong Soon Seng obtained his $\mathrm{PhD}$ (English Literature) from the University of Malaya. He is currently an Assistant Professor in the Department of Languages and Linguistics, Universiti Tunku Abdul Rahman (Kampar Campus) Perak. His research interests include Feminist Writings (Women's Studies), Colonial \& Post-Colonial Literature, and Malaysian Literature in English.

Email: ssfoong@utar.edu.my

Gheeta Chandran obtained her degree in B.A (Hons) Literature in English (UKM) and M.A Postcolonial Literature in English (UKM). She is currently serving as a lecturer in the Department of Languages and Linguistics, Universiti Tunku Abdul Rahman, Perak. She is interested in Colonial and Postcolonial Literature, Diasporic Issues, Mythologies and Folklores and Malaysian Literature in English based research and projects. 
Madness of the East: Demystifying the Colonialist Perspective on Frank Swettenham and Hugh Clifford's Amok

Email: gheetac@utar.edu.my 